\title{
Effects of Error Feedback with Metacognitive Reflection on International Students' Academic Writing
}

\author{
Li-Mei Chen and Chunlei Liu
}

\begin{abstract}
This paper investigates effects of the metacognitive reflection as a feedback dialogue on international students' academic writing. The metacognitive reflection, a process that goes beyond the cognitive process, involves the students to oversee their writing development through the learning process with their instructor. Data from a case study of a group of international students over a period of 16 weeks are used to detect the effects of this method on international students' academic writing. The result of this study is expected to assist second/foreign language (L2) educators to employ effective and efficient pedagogy to help international students improve their L2 writing in the academic setting.
\end{abstract}

Index Terms-Error feedback, L2 writing, metacognitive reflection.

\section{INTRODUCTION}

Writing is a complex process. It is even more complex to write in a second or foreign language (L2). As such, many studies (e.g., [1]-[5]) have pointed out understanding L2 students' special writing difficulties and causes of those difficulties in the process of their writing helps instructors know how to adapt their teaching to assist L2 writers with different linguistic and writing backgrounds. However, how to use a systematic method to effectively and efficiently analyze L2 students' error sources and provide feedback that can actively engage students to improve their writing weaknesses is quite a task. Different variables, e.g., learners' writing experience, L2 proficiency, first language interference, etc., may occur to influence L2 students' writing fluency and accuracy. Even though different analysis methods have been introduced with a hope to identify the areas of difficulty L2 learners encounter in the target language, most common methods, e.g., Contrastive Analysis, Interlanguage Analysis, and Error Analysis, are not easy to put into practice in the U.S. context where students are often from different linguistic background and most instructors do not know all their students' native language (L1). In addition, the methods are rather time-consuming if students are asked to write assigned tasks in two languages, which is impossible in the U.S. college composition classrooms [6].

Therefore, the researchers developed a metacognitive reflection assignment with an aim to tap different L2 students' mastery of their L1 by letting them reflect the influence of their L2 writing to analyze causes of their errors.

Manuscript received March 20, 2017; revised September 5, 2017. This project was supported in part by the IDEA Center Pedagogical Innovation Grants and Faculty Research Seed Grants from Valdosta State University.

The authors are with Valdosta State University, Valdosta, GA 31698 U.S.A. (e-mail: 1chen@valdosta.edu, cliu@valdosta.edu).
Intervened instruction is provided based on each individual student's need. This paper investigates effects of the metacognitive reflection as a feedback dialogue on international students' academic writing. The metacognitive reflection, a process that goes beyond the cognitive process, involves the students to oversee their writing development through the learning process. It starts by having students examine their writing errors as identified by their instructor and analyze their error sources. Based on their analysis, students employ necessary strategies to correct errors. They then reflect on their learning and adjust their learning strategies through the process. Data from a case study of a group of international students over a period of 16 weeks are used to detect the effects of this method on international students' academic writing. The result of this study is expected to benefit L2 educators to employ effective and efficient pedagogy to help international students improve their L2 writing in the academic setting.

\section{LITERATURE REVIEW}

The role of corrective feedback and its effects on L2 writing has been debated since Truscott published his article entitled "The case against grammar correction in L2 writing classes" in 1996 [7]. Based on his analyses from studies by Semke [8], Kepner [9], and Sheppard [10], Truscott claimed that writing corrective feedback should be abandoned because it was ineffective and was harmful to L2 writing. Truscott argued that corrective feedback mainly overlooked the complex process of acquiring the forms and structures of L2, teachers' and students' ability and willingness to participate in giving and receiving corrective feedback, and significant time and effort taken away from more productive aspects in developing students' writing abilities.

In response to Truscott's call, Ferris [11] courter argued that Truscott's claims were premature. There was a methodological problem in his study design and analysis. She pointed out that corrective feedback, when clear, selective, and prioritized, could help at least some learners improve their L2 writing. In response, Truscott [12] acknowledged that many questions remained open, and he, along with Ferris called for further research to investigate long-term benefits of corrective feedback.

To follow this call, the present study aims to examine effects of error correction on international students' writing over time. Specifically, the study attempts to assess the effectiveness of metacognitive reflection along with error codes as a feedback dialogue between the instructor and international students in the academic writing classroom. It supports the recent claim that the most essential issue 
regarding error feedback is "how" instead of "whether" by arguing that it is not whether to provide error feedback but how to communicate error feedback with students and how to engage them in the process of revision to improve their writing (see [13-18]).

\section{Methodology}

\section{A. Research Context and Participants}

The participants comprised of 15 international students, taking Composition Two at Valdosta State University (VSU) in the United States. While the participants were predominantly Korean students (10), they also included students from several other countries, including 2 from Germany, 2 from China and 1 from Spain. Ages ranged from eighteen to early twenties. Most were exchange students in their first or second year of undergraduate studies. If they were not transferring to VSU from another U.S. college or university, they needed to provide one of the following to be admitted into an academic program at VSU: 1) SAT score with a minimum combined Math and Critical Reading score of 900 and a minimum score of 430 for Critical Reading and 400 for Math, 2) TOEFL Score with a minimum score of 69 for the internet-based format or 523 for the paper-based format, 3) IELTS with a minimum score of 6.0,4) completion of the VSU English Language Institute's Level 6 with a B average or better, or 5) proof of having completed the ESL Language Centers' Level 112.

The participants were taking Composition Two, which along with Composition One, is the two-course sequence of The First-Year Writing Program, as a required course under Area A1 of the Core Curriculum for the University System of Georgia. Composition Two focuses on writing skills beyond the levels of proficiency required by Composition One. While Composition One focuses on skills required for effective writing in a variety of contexts, with emphasis on exposition, analysis, and argumentation, and includes introductory use of a variety of research skills, Composition Two focuses on writing skills that emphasize interpretation, evaluation, and incorporation of a variety of more advanced research skills. Composition Two students will learn to organize and present ideas and information effectively in research essays. According the 2017 VSU Online Course Catalog, the two college composition courses provide students with the knowledge and skills needed to satisfy the following learning goals:

Area Al

1) Students will communicate effectively in writing by using appropriate conventions of correctness, style, tone, and organization and by adapting writing to audience and context.

2) Students will find, evaluate, and make inferences from a variety of sources and incorporate this information accurately, correctly, and effectively into their writing work.

\section{Critical Thinking Learning Goal}

Students will identify, evaluate, and apply appropriate models, concepts, or principles to issues, and they will produce viable solutions or make relevant inferences.

\section{B. Procedures}

In this study, students were asked to write four essays adapted from the main text, Guidelines [19], in the course (see Appendix A for the essay prompts), which lasted 16 weeks long. In each four weeks, students were assigned an essay. Other than meeting particular requirements for each essay, their writing in each essay had to demonstrate their awareness of the context and audience and followed conventions of Standard Edited American English. All essays should also conform to the format and documentation conventions of the Modern Language Association (MLA), as established by the latest edition of the MLA Handbook for Writers of Research Papers and articulated in The St. Martin's Handbook [20]. Each essay was tested for plagiarism via the VSU's plagiarism software, Turnitin.

For each essay, students received their instructor's feedback as well as responses from their peers on their drafts with a focus on their idea development and organization. For the final draft, the instructor provided indirect feedback for grammatical and mechanical errors by underlining errors with codes, developed by the researchers based on the handbook adopted in the course (see Appendix B for sample error codes). Students were asked to correct their errors and to complete a reflection assignment (see Appendix C) for each essay. The student-teacher conferences during the essay revision period provided students opportunities to ask questions about their errors, to receive further explanation on their errors from their instructor, and/or to seek advice from their instructor for effective strategies to correct their errors. Both essays and reflection assignments were graded and counted toward the final grade.

\section{Data Collection and Analysis}

The researchers collected the final drafts of all essays and reflection assignments. Data collection started after the permissions from ethics committee of the Valdosta State University and the written consents received from all participants. Totally, 60 essays and 60 reflection assignments were collected. The errors marked by the class instructor were verified by the researchers along with a professor with expertise in teaching composition. The descriptive statistics used in analyzing the essay errors included frequency and means. Students' reflections regarding what they learned through the error correction were analyzed. All students also voluntarily participated in the interviews. The individual interviews were conducted to further understand students' reactions toward the error correction process and the reflection assignments. The researchers took notes throughout the discussion and wrote a summary of key points at the conclusion of each interview. The theme-based content analysis was used to interpret the raw data obtained from the interviews and reflection assignments.

\section{FINDINGS}

\section{A. Error Analysis}

In Essay 1, students wrote 10,565 words in total and made 729 errors, with an average of 14.5 words per error. In Essay 2 , the total words students wrote were 13,643 , with 511 
errors. The average word per error is 26.7 words, indicating that the number of errors dropped significantly in Essay 2. Not only did the errors dropped, but considering the word count, this drop was remarkable. Essay 3 had a total of 13,875 words and 336 errors. The words/error mean for this essay was 41.3. The errors dropped significantly again in Essay 3, but in Essay 4, the errors increased to 440. The number of words also increased to 16,821 , and the mean was 38.2. While it seems that the errors increased 104 more in Essay 4 compared to Essay 3, given the increased word count and the intensity of Essay 4 as a research oriented essay, the difference is not drastic. In addition, students made fewer errors compared to Essays 1 and 2 while writing more in the last essay (see Table I).

TABLE I: TOTAL ERRORS, WORDS, AND MEANS

\begin{tabular}{|l|c|c|c|}
\hline & Total words & Total errors & Mean (words/errors) \\
\hline Essay 1 & 10565 & 729 & 14.5 \\
\hline Essay 2 & 13643 & 511 & 26.7 \\
\hline Essay 3 & 13875 & 336 & 41.3 \\
\hline Essay 4 & 16821 & 440 & 38.2 \\
\hline
\end{tabular}

\section{B. Interviews and Reflections}

Students recognized effects of this innovative method as they indicated how they improved their writing skills over the course of the semester through this method. When being asked to specify how, they pointed out several benefits of the metacognitive reflection on their academic writing. Following listed the top benefits. The number one benefit was learning about their grammar errors. This was the number one benefit for all four essays. This includes learning rules about commas and semi-colons and other grammatical issues. The number two benefit for all four essays was realizing the need to proofread carefully. The students realized that many of their errors could have been caught before if only they would have proofread the paper. The overall number three benefit was learning to utilize external sources for help, e.g., the writing tutoring service provided by VSU's Student Success Center (SSC). This was the number three benefit for the first three essays. The students realized that they could get help from external sources in the areas that they struggled in. The top four and five benefits, however, were mostly different between the four essays. The one benefit that appeared most was learning to structure their papers better, being the number four benefit in Essay Three and the number three benefit in Essay Four. Many of these various benefits show what the students needed to improve on, such as using description, writing succinctly, incorporating research into writing, or using the MLA style. Two of these dealt with means to learn more about how to improve their writing, either through help from the instructor or help from their peers (See Table II).

TABLE II: TOP FIVE BENEFITS

\begin{tabular}{|c|c|c|c|c|c|}
\hline & Top 1 & Top 2 & Top 3 & Top 4 & Top 5 \\
\hline Essay 1 & 1 & 2 & 3 & 5 & 8 \\
\hline Essay 2 & 1 & 2 & 3 & 6 & 9 \\
\hline Essay 3 & 1 & 2 & 3 & 4 & 10 \\
\hline Essay 4 & 1 & 2 & 4 & 7 & 11 \\
\hline
\end{tabular}

1 = learn about grammar errors; 2 = understand the importance of proofreading; 3 = learn to use external sources for help; $4=$ learn how to structure their paper better; $5=$ learn to write succinctly; $6=$ learn to write more descriptively; $7=$ learn how to incorporate research into writing; $8=$ learn how to seek help from the instructor; $9=$ learn how to seek help from peers; $10=$ learn how to study English writing; $11=$ learn how to do the MLA style, e.g., citations and documentation.

\section{DISCUSSION AND CONCLUSION}

International students often find the writing demands in the college composition courses very challenging. They are learning English while learning academic writing, so they encounter additional rhetorical, lexical, syntactic, and grammatical errors compared to their native peers. This study reveals positive effects of using the metacognitive reflection along with error codes as a feedback dialogue on international students' academic writing. It benefits not only the composition instructor but also the international student writers. Through this method, the instructor can facilitate her communication of feedback with the students. Using the error codes, the instructor can quickly assess students' writing errors by underlining each error the student makes and inserting an error code by or under each underlined error, which turns her assessment efficient. When she shares assessments with her students, students can refer to the codes and sources to understand their errors and ways to correct their errors. After their correction, students can further understand their writing strengths and weaknesses via reflecting their learning process through analyzing their errors and strategies they employed to correct their errors. Additionally, the instructor can track each student's progress through the term, compare each student's error pattern through different essays, track the whole class's progress, track top resistant errors (see Table 3 for an example), and assess students' use of strategies in error correction. With this information, the instructor can further understand students' learning difficulties during the writing process, provide necessary instruction to help students fix resistant errors and/or suggest strategies for error correction. All of these, in turn, help to improve students' writing over the time.

TABLE III: SAMPLE ERROR COMPARISON

\begin{tabular}{|c|c|c|c|c|c|}
\hline \multirow{2}{*}{$\begin{array}{c}\text { Code } \\
\#\end{array}$} & \multirow{2}{*}{ Type of Error } & \multicolumn{2}{|c|}{ \# of errors } & \multicolumn{2}{c|}{ Rank } \\
\cline { 3 - 6 } & Essay 1 & Essay 2 & Essay 1 & Essay 2 \\
\hline 4 & Awkward wording & 171 & 136 & 6 & 5 \\
\hline 7 & $\begin{array}{c}\text { Incorrect verb } \\
\text { tense }\end{array}$ & 262 & 116 & 3 & 7 \\
\hline 20 & Wordy & 89 & 83 & 10 & 9 \\
\hline 25 & Comma errors & 329 & 235 & 2 & 2 \\
\hline 31 & Lower/upper case & 125 & 120 & 8 & 6 \\
\hline 32 & Unclear meaning & 148 & 114 & 7 & 8 \\
\hline 33 & Preposition errors & 241 & 139 & 4 & 4 \\
\hline 34 & Article missing & 384 & 258 & 1 & 1 \\
\hline 35 & Improper noun & 209 & 172 & 5 & 3 \\
\hline 39 & Improper words & 96 & 80 & 9 & 10 \\
\hline
\end{tabular}

While the role of error feedback and its effects on L2 writing has been debated for over two decades (see the main debates from [7], [11], [12], [21], and [22]), this study supports the argument that it is not whether to provide feedback but how to do it to engage students (see [13-18]). It further proves the importance for instructors to incorporate collaborative dialogue into error feedback to enhance L2 students' writing.

Finally, this case study allows the researchers to investigate error feedback as an empirical inquiry in depth 
and within its real-life context [23]. The insights learned from this study can be construed as tentative hypotheses to guide future research design to further understand error feedback with a larger population or in different contexts.

\section{Appendix A: Major Writing Assignments}

\section{Essay 1: Write from experience}

Write an essay (3-4 pages or 750-1000 words) in which you describe an experience - or series of related experiences - that has led you to a new insight or point of view. Provide details and examples that enable readers to see, hear, and feel what happened.

\section{Essay 2: Relating reading to experience}

Write an essay (4-5 pages or 1000-1250 words) in which you compare the ideas and experiences discussed in one or more reading in Guidelines Ch. 3 to your own experience and attitudes. Show how the generalizations, theories, or experiences of another writer correspond to or contradict your own background knowledge and experience. Your purpose is to test the truth, or validity, of the author's ideas. To accomplish this goal, you will need to incorporate ideas and details from the reading into your own essay.

Essay 3: Analyzing an argumentative essay

Write an essay (4-5 pages or 1000-1250 words) in which you analyze the strengths and weaknesses of another writer's argument we did not discuss in Guidelines Ch. 4. Explain what the author says, how well the author's points are made, and what points the author may have overlooked. Your purpose is to establish and support your own position agreeing or disagreeing with the author's viewpoint. To accomplish this goal, you will need to incorporate ideas and details from the reading into your essay. You may write about more than one reading from Guidelines, for example, by using evidence provided by one writer to refute an argument presented by another writer.

\section{Essay 4: Library and Web-based research}

Write an essay (5-6 pages or 1250-1500 words, excluding the works cited page) in which you draw from library and Web-based research to investigate an issue that is addressed in Guidelines, such as cross-cultural communication, racial and cultural discrimination, legal and illegal immigration, educational opportunities for disadvantaged learners, or grading practices in schools and colleges. Alternatively, you may investigate another issue that you want to learn more about. Consult multiple sources in order to discover a variety of perspective on your chosen topic. Your purpose is to answer a question or offer a solution to a problem. To accomplish this goal, you will need to build on the existing research by incorporating material from published sources, including scholarly articles and books. These sources (at least 6 sources must be from the VSU's Odum library), which can include both print and electronic works, should be effectively integrated into the essay to support or illustrate a central idea or thesis.

APPENDIX B: SAMPLE ERROR CODES

\begin{tabular}{|c|c|c|c|}
\hline$\#$ & Chapter & Type of Error & Reference \\
\hline 1 & Ch. 31 & $\begin{array}{c}\text { Subject-verb } \\
\text { disagreement }\end{array}$ & $\begin{array}{c}\text { Consult the St. Martin's handbook, } \\
\text { Ch. 31, for how to fix the error. }\end{array}$ \\
\hline 2 & Ch. 32 & $\begin{array}{c}\text { Pronoun-noun } \\
\text { (antecedent) } \\
\text { disagreement }\end{array}$ & $\begin{array}{c}\text { Consult the St. Martin's handbook, } \\
\text { Ch. 32, for how to fix the error. }\end{array}$ \\
\hline
\end{tabular}

\begin{tabular}{|c|c|c|c|}
\hline 3 & Ch. 34 & Confusing shift & $\begin{array}{c}\text { Sudden shifts in voice, verb tense, } \\
\text { person/number, direct/indirect } \\
\text { discourse, and/or tone/diction -- } \\
\text { Consult the St. Martin's handbook, } \\
\text { Ch. 34, for how to fix the error. }\end{array}$ \\
\hline
\end{tabular}

Appendix C: Reflection Assignment

Instruction: Follow these steps in order to write a reflection on your essay:

1. List total words in your original essay (the one your professor graded):

2. List total errors in your essay (The one marked by your professor):

3. In the following table, list the errors you made in your essay and state the causes.

a. Total \# of the error: You can use tally marks to count the total number of each error you made in your essay.

b. Rank of the error: Based on your tally marks, rank your errors as 1 -- the most frequent error; 2 - second most frequent error; 3 - third most frequent error; 4 - fourth most frequent error; etc.

c. List your top five errors in order (from the most frequent to the least):

\#1:

\#2:

\#3:

\#4:

\#5:

d. Cause of the error: For each error, briefly explain why you made such an error (cause of the error). Was it due to the influence of your first language, your limited English ability, your overgeneralization of English rules, your overlook, or others? If others, please specify what others mean.

4. Now, read your professor's comments carefully. Correct each error in your paper. Once you have revised all your errors, highlight or underline what you corrected in your revised version.

5. Strategy used to fix the error: For each error type, state what strategy you use to correct the error, e.g., consulting the handbook, asking your peer's help, checking with the tutor from Student Success Center, doing research about the error and self-correct it, consulting your professor, or others. If others, please specify your strategy.

6. Finally, write 300-500 words to explain your writing process, including how you developed your essay, difficulties you encountered, ways to deal with those difficulties, your writing strengths and weaknesses, what you learned through the error correction, and your plan for improvement. Attach your typed work with this reflection worksheet.

\begin{tabular}{|r|c|c|c|c|}
\hline $\begin{array}{c}\text { Error } \\
\#\end{array}$ & $\begin{array}{c}\text { Total } \\
\text { number of } \\
\text { the error }\end{array}$ & $\begin{array}{c}\text { Rank of the } \\
\text { error }\end{array}$ & $\begin{array}{c}\text { Cause of } \\
\text { the error }\end{array}$ & $\begin{array}{c}\text { Strategy used } \\
\text { to fix the } \\
\text { error }\end{array}$ \\
\hline 1 & & & & \\
\hline 2 & & & & \\
\hline 3 & & & & \\
\hline 4 & & & & \\
\hline
\end{tabular}




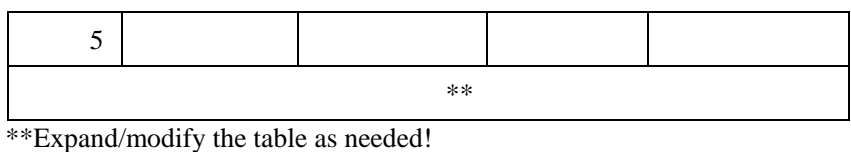

\section{REFERENCES}

[1] P. Bennui, "A study of L1 interference in the writing of Thai EFL students," Malasian Journal of ELT Research, vol. 4, pp. 72-102, 2008.

[2] B. Bhela, "Native language interference in learning a second language: Exploratory case studies of native language inference with target language usage," International Education Journal, vol. 1, no. 1, pp. 22-31, 1999

[3] A. Y. W. Chan, "Syntactic transfer: Evidence from the interlanguage of Hong Kong Chinese ESL learners," The Modern Language Journal, vol. 88, no. 1, pp. 56-74, 2004.

[4] J. Myles, "Second language writing and research: The writing process and error analysis in student texts," TESL-EJ, vol. 6, no. 2, pp. 1-19, 2002.

[5] T. Thep-Ackrapong, "Teaching English in Thailand: An uphill battle," Journal of Humanities Parithat, Srinakharinwirot University, vol. 27, no. 1, pp. 51-62, 2005.

[6] S. Watcharapunyawong and S. Usaha, "Thai EFL students' writing errors in different text types: The interference of the first language," English Language Teaching, vol. 6, no. 1, pp. 67-78, 2013.

[7] J. Truscott, "The case against grammar correction in L2 writing classes," Language Learning, vol. 46, pp. 327-369, 1996.

[8] H. Semke, "The effects of the red pen." Foreign Language Annals, vol. 17, pp. 195-202, 1984.

[9] C. G. Kepner, "An experiment in the relationship of types of written feedback to the development of second-language writing skills," Modern Language Journal, vol. 75, pp. 305-313, 1991.

[10] K. Sheppard, "Two feedback types: Do they make a difference?" Regional Language Center Journal, vol. 23, pp. 103-110, 1992.

[11] D. Ferris, "The case for grammar correction in L2 writing classes: A response to Truscott," Journal of Second Language Writing, vol. 8, no. 1, pp. 1-11, 1999.

[12] J. Truscott, "The case for "The case against grammar correction in 12 writing classes': Response to Ferris," Journal of Second Language Writing, vol. 8, no. 2, pp. 111-122, 1999.

[13] N. W. Evans, K. J. Hartshorn, R. M. McCollum, and M. Wolfersberger, "Contextualizing corrective feedback in second language writing pedagogy," Language Teaching Research, vol. 14, no 4, pp. 445-463, 2010.

[14] A. Marzban, "Collaborative negotiated feedback versus teacher-written feedback: Impact on Iranian intermediate EFL learners' writing," Theory and Practice in Language Studies, vol. 4, no. 2, pp. 293-302, 2014.

[15] S. Granville, and L. Dison, "Making connections through reflection: Writing and feedback in an academic literacy programme," Southern African Linguistics and Applied Language Studies, vol. 27, no. 1, pp. 53-63, 2009.

[16] D. Watson, "Teaching teachers to think: Reflective journaling as a strategy to enhance students' understanding and practice of academic writing," Journal of College Teaching \& Learning, vol. 7, no 12, pp.11-18, 2010.
[17] R. Hirschel, "A qualitative study in grammar logs," International Journal of Pedagogies and Learning, vol. 6, no. 2, pp. 126-139, 2011.

[18] A. Kassim, and L.L. Ng, "The roles of collaborative dialogue in enhancing written corrective feedback efficacy," Malaysian Journal of ELT Research, vol. 10, no. 1, pp. 16-30, 2014.

[19] R. Spack, Guidelines; A Cross-Cultural Reading/Writing Text, Cambridge, 2007.

[20] A. Lunsford, St. Martin's Handbook; Boston: Beford/St. Martin's, 2015.

[21] D. Ferris, Treatment of Error in Second Language Writing; Ann Arbor: The University of Michigan Press, 2002.

[22] D. Ferris, "The 'grammar correction' debate in L2 writing: Where are, and where do we go from here?" Journal of Second Language Writing, vol. 13, pp. 49-62, 2004.

[23] R. K. Yin, Case Study Research: Design and Methods; SAGE Publications Ltd: London, 2009.

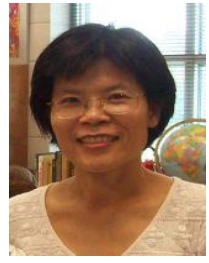

Li-Mei Chen received her $\mathrm{PhD}$ from Ohio State University in second and foreign language education, with specialization of applied linguistics/ESOL, minors in language testing and research methods. As a professor of applied linguistics/English in the Department of English at Valdosta State University, she teaches linguistics, grammar, along with the first-year college writing and professional writing courses. Her research interests include L2 writing, technology-integrated language teaching, L2 teacher education, and language testing and assessment. The awards/grants she has received include VSU's President'S Award for Excellence in the Scholarship of Teaching and Learning, Online Development Grant, Technology and Multimedia Award in English Teaching, and TOEFL Grant She has published articles on L2 writing, technology and language teaching, teacher education for ESL and EFL, and testing effects on language education.

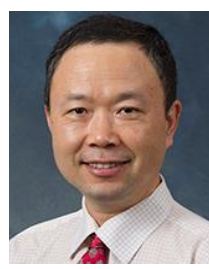

Chunlei Liu received his bachelor and master of science degrees from Wuhan University in China, and his Ph.D. in computer and information science from the Ohio State University in United States, with a major in computer networks and minors in scientific computing and computer graphics.

He was an assistant professor at Wuhan University from 1991 to 1995 and worked as a System Architect from 2000 to 2003 in Lucent Technology Bell Labs. He was an Assistant Professor from 2003 to 2005 at Sorrell College of Business at Troy University where he taught various information systems and business courses. He is now a Professor in the Department of Computer Science at Valdosta State University. He has been teaching various computer science, information systems and e-commerce courses. He was the ABET Accreditation Coordinator for VSU's Computer Science program and led the program's successful accreditation in 2016.

Dr. Liu's research interest is in computer networks, scientific computing, computer science education, accreditation and assessment. He has published more than 85 journal articles, conference papers and book chapters, and received 13 internal and external grants. He served in the editorial board of several journals and many conference committees. 